\author{
${ }^{\odot}$ C. В. Врублевська
}

Запорізъкий державний медичний університет

\title{
ПЕРВИННА ПРОФІЛАКТИКА АТОПІЧНИХ ЗАХВОРЮВАНЬ У ДІТЕЙ РАННЬОГО ВІКУ НА АНТЕНАТАЛЬНОМУ ЕТАПІ
}

ПЕРВИННА ПРОФІЛАКТИКА АТОПІЧНИХ ЗАХВОРЮВАНЬ У ДІТЕЙ РАННЬОГО ВІКУ НА АНТЕНАТАЛЬНОМУ ЕТАПІ. Материнські алогенні та ксеногенні імуногени можуть спричинити сенсибілізацію плода за рахунок контакту його шкіри і шлунково-кишкового тракту з амніотичною рідиною вже з 19-го тижня вагітності, таким чином підвищуючи ризик розвитку гіперчутливості I та II типів. Відсутність доказів превентивного ефекту гіпоалергенної дієти в період вагітності відносно алергічних захворювань у дітей не дозволяє рекомендувати виключення певних харчових продуктів з раціону вагітних при наявності генетичного ризику атопії в дітей. Ми пропонуємо на антенатальному етапі комплекс профілактичних засобів, який базується на виключенні контакту вагітних жінок, хворих на атопічне захворювання, тільки 3 причинно-вагомими алергенами, та своєчасне лікування загострень алергічних захворювань у них. Споживання жінками різноманітних якісних харчових продуктів під час вагітності тільки сприяє формуванню харчової толерантності в майбутніх немовлят і, тим самим, $€$ дієвим засобом профрілактики атопії у дітей раннього віку.

ПЕРВИЧНАЯ ПРОФИЛАКТИКА АТОПИЧЕСКИХ ЗАБОЛЕВАНИЙ У ДЕТЕЙ РАННЕГО ВОЗРАСТА НА АНТЕНАТАЛЬНОМ ЭТАПЕ. Материнские аллогенные и ксеногенные иммуногены могут вызвать сенсибилизацию плода за счет контакта его кожи и желудочно-кишечного тракта с амниотической жидкостью уже с 19-й недели беременности, таким образом повышая риск формирования гиперчувствительности I и II типов. Исключение определенных пищевых продуктов из рациона беременных при наличии генетического риска атопии у детей не позволительно из-за отсутствия доказательств превентивного эфффекта гипоаллергенной диеты в период беременности относительно аллергических заболеваний у детей. Мы предлагаем на антенатальном этапе комплекс превентивных средств, основанный на исключении контакта беременных женщин, больных атопическими заболеваниями, только с причинно-значимыми аллергенами, и своевременное лечение обострений аллергических заболеваний у них. Употребление женщинами разнообразных качественных пищевых продуктов во время беременности только способствует фрормированию пищевой толерантности у будущих младенцев и, тем самым, является действенным средством профилактики атопии у детей раннего возраста.

PRIMARY PREVENTION OF ATOPIC DISEASES IN INFANTS ON ANTENATAL STAGE. Maternal fetal allogeneic and xenogeneic immunogens can cause sensitization from 19th week of pregnancy due to the penetration of amniotic fluid through the skin and the gastrointestinal tract, thus increasing the risk of hypersensitivity type I and II. The lack of evidence of a preventive effect of hypoallergenic diets during pregnancy regarding allergic diseases in children can not recommend exclusion of food from the diet of pregnant women in the presence of genetic risk of atopy in children. We offer at the antenatal stage a set of preventive tools, based on the exclusion of contact of pregnant women, patients with atopic diseases, only with cause-significant allergens and early treatment of exacerbations of allergic disease in it. The use of various qualitative food during pregnancy only promotes tolerance in the food of the future baby and thus is an effective means of preventing allergies in infants.

Ключові слова: епігенетика, атопія, діти, профрілактика.

Ключевые слова: эпигенетика, атопия, дети, профилактика.

Key words: epigenetics, atopy, children, prevention.

ВСтУП. На ранніх стадіях онтогенетичного розвитку для організму плода і немовляти при первісному програмуванні адаптивної ділянки імунної пам'яті має велике значення антигенна інооомація, яку вперше отримує організм дитини.

Синтезовані клітинами матері алогенні імуногени (специфічні IgE та інтерлейкіни) й алергени, ксеногенні імуногени (ксеногени) починають проникати в організм плода через судини плаценти і з амніотичної рідини через шкіру та шлунково-кишковий тракт з 19-го тижня антенатального розвитку [2-6]. Вони підвищують ризик виникнення адаптивної імунної амнезії, на тлі якої зростає ризик розвитку гіперчутливості I і II типів. Крім того, під впливом несприятливих епігенетичних фракторів у геномі плода знижується метилування ДНК у локусі Th2-клітин протягом дифреренціювання 3 наївних Т-клітин, що корелює зі збільшенням ацетиляції гістонів і підвищенням експресії IL-4, IL-5 i IL-13 (В. А. Козлов, 2012).
Окремими дослідженнями доведений корелятивний зв'язок атопічних захворювань дітей у неонатальний період з підвищеним вмістом специфрічних IgE матері в пуповинній/перисреричній венозній крові [2]. G. Lack (2005) вказує на те, що в дитини спостерігається семиразове збільшення ризику алергії до арахісу при наявності атопії у батька або близьких родичів [3]. Проте з необхідністю призначення гіпоалергенної дієти вагітним жінкам та матерям-годувальницям погоджуються не усі вчені. Так, експерти комітету ВООЗ із профрілактики алергії вважають доречним гіпоалергенне харчування лише для тих вагітних жінок, які мають алергічні прояви захворювання, або тих, які завагітніли від чоловіків з ускладненим алергологічним анамнезом [2].

Комплекс профрілактичних заходів, на нашу думку, може попередити розвиток атопічних захворювань шляхом «виключення» (метилування) генів схильності до атопії. Тому розробка ефективних засобів профілактики 
розвитку алергопатології вже під час вагітності стає найбільш актуальною та ефективною.

МАТЕРІАЛИ ТА МЕТОДИ. Дизайн дослідження. Шляхом катамнестичного аналізу медичної документації (амбулаторних карт) 1210 вагітних жінок центру міста та 1310 вагітних, які проживають у зоні відносного екологічного благополуччя, ми відібрали вагітних жінок 3 високим ступенем ризику виникнення алергічних захворювань у майбутніх немовлят $(n=303)$ для проведення первинної профрілактики атопічних захворювань дітей на перинатальному етапі. До групи дослідження ввійшли 225 вагітних жінок, які мали загострення алергічного захворювання під час вагітності, та 78 жінок, які завагітніли від чоловіків з атопічним захворюванням. До складу контрольної групи ввійшли вагітні жінки 3 необтяженим алергологічним анамнезом $(n=2520)$.

Meтоди дослідження. Отримані у процесі катамнестичного аналізу медичної документації (амбулаторних карт) дані було оброблено методом математичної статистики за допомогою стандартних пакетів програм Microsoft Excel ta Statistica for Windows.

РЕЗУЛЬТАТИ ДОСЛІДЖЕННЯ ТА ЇХ ОБГОВОРЕННЯ. За результатами катамнестичного дослідження (діагр. 1), загальний рівень атопічних захворювань в 1,65 раза ( $<<0,05)$ був вищим у загазованій зоні $(11,23 \%, 136$ осіб), ніж у зоні відносного благополуччя (6,79 \%, 89 жінок).

Захворюваність на респіраторний алергоз в екологічно несприятливій зоні м. Запоріжжя у 4 рази вища (3,83 \% проти 0,91 \% вагітних), переважно за рахунок гіперчутливості до пилкових алергенів трав - 3,58\% проти 0,91 \%, що пояснюється негативним техногенним впливом аерозольних ксеногенів великого промислового міста. Гіперчутливість до пилкових алергенів превалює за рахунок бур'янів - у 4 рази вища, ніж до пилку дерев та лугових трав. Алергічні реакції на епідермальні алергени тварин виявлено переважно до епідермальних алергенів кішок та собак (діагр. 2).

При опитуванні вагітних жінок щодо медикаментозної алергії терапевти робили акцент на виявленні алергічних реакцій на антибіотики (пеніциліни - 18-16 \%, інші антибіотики - 6-7 \%), анестетики - 6-7 \%, НПВП - 7-5 \%, вітаміни - 3-2 \%, препарати крові - $2 \%$. Додатково були виявлені поодинокі випадки алергічних реакцій на естроген-прогестероновмісні медикаменти (ультражестан), антигістамінні засоби (діазолін, супрастин, піпольфен), метопролол, преднізолон, антисептики.

Отримані нами результати дозволяють адаптувати рекомендації експертів ВООЗ і Всесвітньої організації алергії «Запобігання алергії та алергічній астмі» (World Allergy Organization - International Association of Allergology and Clinical Immunology,WAO-IAACI) [1, 3] до нашого регіону.

Вплив харчових обмежень у перші два триместри вагітності на розвиток у подальшому атопічних хвороб у дітей до кінця не вивчено [1-5]. У зв'язку з цим, будьяка корекція раціону харчування вагітної повинна бути строго обґрунтована. Відсутність переконливих доказів превентивного ефекту гіпоалергенної дієти в період вагітності відносно алергічних захворювань у дітей не дозволяє, на нашу думку, рекомендувати виключення певних харчових продуктів з раціону вагітних навіть при наявності генетичного ризику атопії в дітей.

Ми пропонуємо виділити первинну профілактику:

1) на антенатальному етапі - повинна базуватися на виключенні контакту вагітних жінок, хворих на атопічне захворювання, виключно з причинно-вагомими алергенами та своєчасному лікуванні загострень алергічних захворювань у них;

2) на постнатальному етапі- обмеження облігатних для новонароджених дітей харчових алергенів у раціоні харчування жінок-годувальниць.

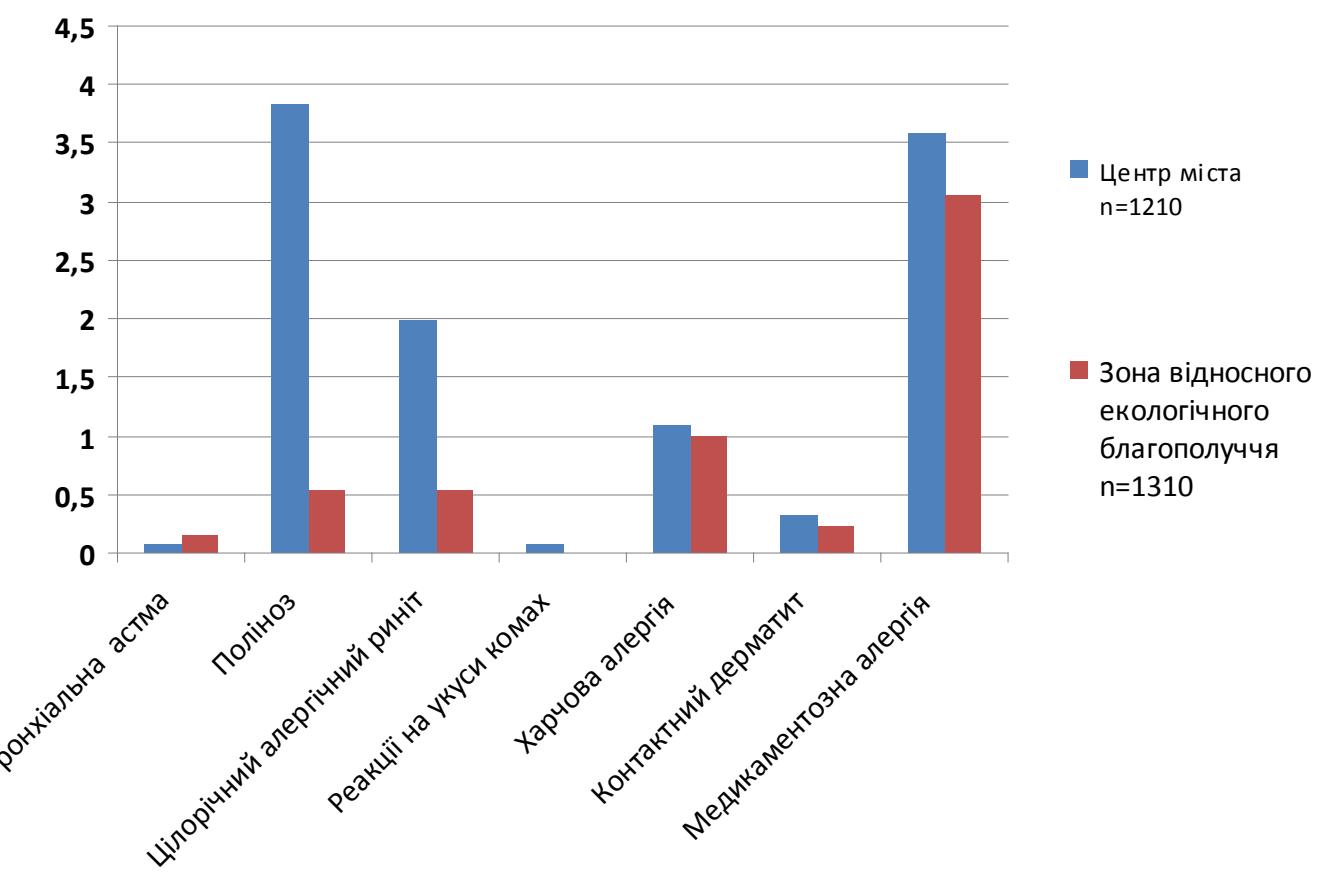

Діагр. 1. Структура алергопатології вагітних жінок загазованого центру міста порівняно із зоною відносного благополуччя. 


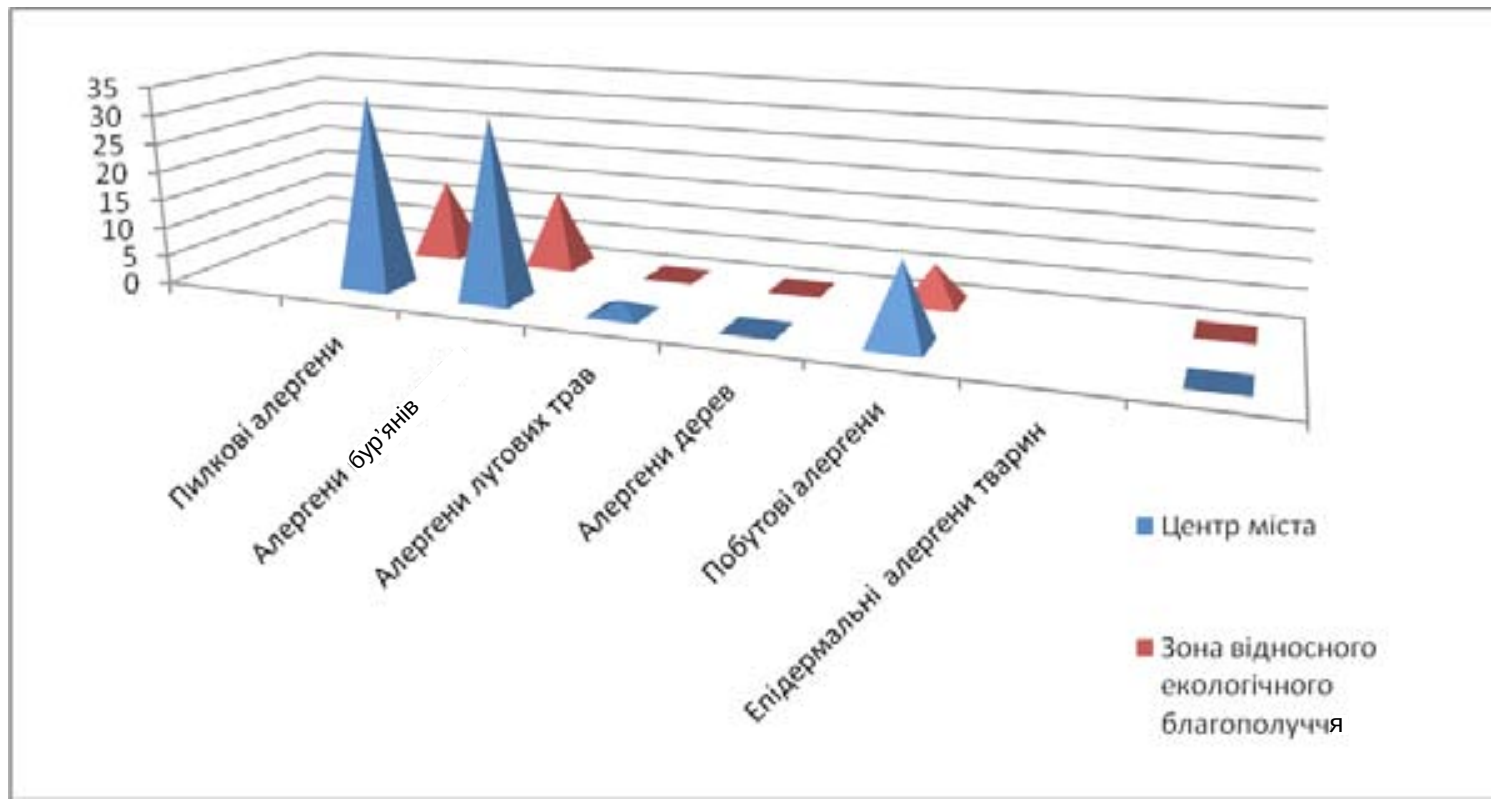

Діагр. 2. Частота виявлення сенсибілізації до різних видів алергенів серед вагітних залежно від регіонального розташування (за даними шкірного алерготестування).

Первинна антенатальна профілактика, на нашу думку, повинна включати формування харчової толерантності, зниження гострої респіраторної та гельмінтно-паразитарної захворюваності шляхом дотримування гіпоалергенної дієти, уникнення професійних шкідливостей; виключення тютюнокуріння, вживання алкогольних напоїв, інших шкідливих звичок, обмеження застосування фрармакологічних засобів; зниження рівня експозиції причинно-вагомими екзогенними алергенами; уникнення вірусних і бактеріальних інфекцій; лікування ускладнення вагітності, супутніх алергічних та інших соматичних хвороб $[1,2,6-8]$.

І. Я. Кінь, М. В. Гмошінська (2005-2012) [1] пропонують виключити з раціону майбутніх мам з груп ризику розвитку в дітей алергії при грудному вигодовуванні копчені ковбаси (варено- та сирокопчені), копчену рибу, скумбрію, раки, креветки, йогурти з фруктовими наповнювачами, глазуровані сирки, мед, шоколад, какао, шоколадні цукерки, з овочів - томати, з фруктів і ягід - банани, цитрусові, тропічні плоди, полуницю, малину, виноград. Ми рекомендуємо всім вагітним жінкам, і здоровим, і тим, які належать до групи ризику виникнення алергії, обмежувати тільки синтетичні гістаміно-лібератори - барвники, приправи, ароматизатори, консерванти, емульгатори, стабілізатори, розрихлювачі, імітатори смаку, антиокиснювачі та ін. Для порівняння в таблиці 1 наведено набір продуктів для вагітних жінок з групи ризику розвитку в їх дітей харчової алергії.

Молоко при непереносимості краще замінити кисломолочними продуктами або козячим молоком. 3 кисломолочних продуктів можна використовувати будь-які: кефрір, кисле молоко, ряжанку, йогурти без фруктових наповнювачів. 3 круп - переважно гречану, рисову, кукурудзяну (не рекомендується манка, а вівсянку, пшоно, перловку, макаронні вироби можна споживати не частіше 2 разів на тиждень). Слід збільшити в раціоні частку рослинних жирів у вигляді олії: соняшникової, кукурудзяної, оливкової. Вершкове масло - краще в топленому вигляді. Майонез, кулінарний жир із харчування виключаються. 3 м'яса краще споживати нежирну свинину, яловичину, кролятину, індичатину, курятину. Якщо жінка переносить рибу, то немає показань до виключення її з раціону (як правило, не частіше 1-2 разів на тиждень), перевагу слід віддати річковій рибі.

3 кондитерських виробів можна галети, несолодке печиво, зесрір, пастилу. Не треба зловживати цукром, бо він може посилювати алергічну дію. Якщо жінка переносить яйця, то достатньо 2-3 штук на тиждень. 3 фрруктів бажані печені яблука (зелені), груші, вишня, біла черешня, смородина біла і червона, обережніше 3 чорною смородиною, абрикосами, персиками. Із соків і напоїв корисніші натуральні соки, які не містять цукру, зелений чай, питна вода в пляшках, хліб - житній або 3 висівками (наказ МО3 України від 05.07.2011 р. № 417). Консерви тільки для дитячого харчування - овочеві, фрруктові, м'ясні, рибні (табл. 2) .

Як показали дослідження І. Я. Кінь, М.В.Гмошінської (Москва, 2012) [1, 2], крім високоалергенних продуктів, причиною розвитку алергічних реакцій можуть стати продукти, які використовуються у великій кількості й постійно. Саме тому з метою профрілактики алергії ми рекомендуємо вагітним жінкам урізноманітнити свій раціон, використовувати різні продукти, не віддавати перевагу одному продукту. Вищенаведені результати катамнестичного дослідження довели, що наслідки шкідливих звичок та несприятливих умов праці, напружений емоційний фрон, хронічні інфекційні та соматичні захворювання батьків 3 одного боку та вплив забрудненого навколишнього середовища, споживання напівсинтетичних продуктів можуть негативно впливати на епігеном дитини і сприятимуть фрормуванню «матриці» атопічної патології. Профрілактику алергічних захворювань у майбутніх немовлят, на нашу думку, треба починати вже з антенатального періоду. 
Педіатрія

Таблиця 1. Асортимент продуктів, рекомендованих і нерекомендованих вагітним жінкам та жінкамгодувальницям 3 груп ризику розвитку в їх дітей харчової алергії $[1,2,6,7]$

\begin{tabular}{|c|c|c|c|}
\hline $\begin{array}{c}\text { Група } \\
\text { продуктів }\end{array}$ & $\begin{array}{c}\text { Допускаються в кількості, } \\
\text { рекомендованій здоровим жінкам }\end{array}$ & Обмежуються & Виключаються \\
\hline М'ясопродукти & $\begin{array}{l}\text { Свинина нежирна, м'ясо кролика, індич- } \\
\text { ки, курятина, яловичина, телятина * }\end{array}$ & \begin{tabular}{|l|} 
Ковбаси варені, напівфабри- \\
кати, сосиски, сардельки 2 рази \\
на тиждень
\end{tabular} & $\begin{array}{l}\text { Сиро- і варенокопчені ковба- } \\
\text { си, консерви }\end{array}$ \\
\hline Рибопродукти & Тріска, хек, мінтай, судак, окунь & $\begin{array}{l}\text { Оселедець солоний, жирні сор- } \\
\text { ти риби } 1 \text { раз на тиждень }\end{array}$ & $\begin{array}{l}\text { Скумбрія, морепродукти } \\
\text { консерви }\end{array}$ \\
\hline Яйця & - & До 3 шт. на тиждень & - \\
\hline $\begin{array}{l}\text { Молочні про- } \\
\text { дукти }\end{array}$ & $\begin{array}{l}\text { Молоко, вершки, кисломолочні продук- } \\
\text { ти без ароматизаторів і наповнювачів } \\
\text { (кедрір, ряжанка, йогурти, кисле молоко), } \\
\text { сир, сметана }\end{array}$ & $\begin{array}{l}\text { Кисломолочні продукти з аро- } \\
\text { матизаторами і фрруктовими } \\
\text { наповнювачами, глазуровані } \\
\text { солодкі сирки }\end{array}$ & - \\
\hline $\begin{array}{l}\text { Крупи, } \\
\text { макаронні } \\
\text { вироби }\end{array}$ & $\begin{array}{l}\text { Гречана, кукурудзяна, рисова, вівсяна } \\
\text { крупи, макарони вищого гатунку }\end{array}$ & - & - \\
\hline $\begin{array}{l}\text { Хлібобулочні } \\
\text { вироби }\end{array}$ & $\begin{array}{l}\text { Житньо-пшеничний, з висівками, сушки, } \\
\text { сухарі }\end{array}$ & $\begin{array}{l}\text { Здобні хлібобулочні вироби, } \\
\text { бісквіти } 2 \text { рази на тиждень }\end{array}$ & \\
\hline Харчові жири & $\begin{array}{l}\text { Очищена олія: з кукурудзи, соняшнику, } \\
\text { сої, оливкова олія, вершкове масло }\end{array}$ & Маргарин & Майонез \\
\hline $\begin{array}{l}\text { Цукор і } \\
\text { кондитерські } \\
\text { вироби }\end{array}$ & $\begin{array}{l}\text { Галети, печиво (нездобне), зесрір, пасти- } \\
\text { ла, варення, повидло, джеми (яблуко, } \\
\text { груша) в еквівалентній кількості }\end{array}$ & Цукор до 40 г на добу & $\begin{array}{l}\text { Торти, тістечка, шоколадні ви- } \\
\text { роби, мед, джеми, варення, } \\
\text { повидло (вишня, полуниця), } \\
\text { цитрусові, тропічні фррукти, } \\
\text { виноград }\end{array}$ \\
\hline Овочі & $\begin{array}{l}\text { Капуста всіх сортів, картопляні вироби, } \\
\text { гарбуз, морква, кабачки, молоді огірки }\end{array}$ & Томатні вироби & \\
\hline Фрукти & $\begin{array}{l}\text { Яблука, груші, абрикоси, персики, диня, } \\
\text { черешня жовта, смородина чорна та } \\
\text { біла, слива світлого кольору } \\
\end{array}$ & $\begin{array}{l}\text { Банани, цитрусові, тропічні } \\
\text { фррукти, виноград, полуниця, } \\
\text { малина }\end{array}$ & \\
\hline Соки і напої & $\begin{array}{l}\text { Соки натуральні, бажано з абрикоса, } \\
\text { груші, яблука, персика, сливи, вишні, } \\
\text { натуральні фрруктові напої, чай, питна } \\
\text { бутильована вода }\end{array}$ & $\begin{array}{l}\text { Соки томатний, апельсино- } \\
\text { вий, виноградний, з тропічних } \\
\text { сруктів, з полуниці та мали- } \\
\text { ни, безалкогольні газовані й } \\
\text { негазовані прохолодні напої, } \\
\text { какао } \\
\end{array}$ & $\begin{array}{l}\text { Пиво (в тому числі безалко- } \\
\text { гольне), алкогольні напої }\end{array}$ \\
\hline
\end{tabular}

Примітка. * - за умови переносимості.

Таблиця 2. Продукти харчування, харчові добавки й лікарські препарати, що спричинюють розвиток псевдоалергічних реакцій (АДАІР, 2005)

\begin{tabular}{|l|l|l||}
\hline \multicolumn{1}{|c|}{ Продукт харчування } & \multicolumn{1}{|c|}{ Харчова добавка } & \multicolumn{1}{|c|}{ Лікарський засіб } \\
\hline Консервовані продукти, копчені, квашені та & Барвники, приправи, & Папаверин, атропін, НПВП, бром, \\
мариновані продукти, кава, какао, шоколад, & ароматизатори, кон- & йод, антибіотики, засоби для нар- \\
цитрусові фрукти, рибні продукти, морепродукти, & серванти, емульгатори, & козу, вітаміни, солі жовчних кислот, \\
томатні вироби, капуста, горіхи, гриби, насіння, & стабілізатори, розрихлювачі, & білкові препарати, препарати крові \\
вина, ферментовані сири, суниця, полуниця, & антиокиснювачі та ін. & та ін. \\
печінка, свинина та ін. & & \\
\hline
\end{tabular}

ВИсновкИ. 1. Враховуючи викладене, ми повинні використовувати принципи епігенетичного підходу для розробки превентивних заходів для попередження розвитку атопічних реакцій у дітей, зокрема з відповідними організаційними заходами щодо поліпшення контролю якості харчової продукції, розробки раціональних підходів до режиму праці, відпочинку та, особливо, харчування вагітних жінок і жінок-годувальниць, що повинно виклю- чити вплив та приймання ксенобіотиків, як дієвий засіб первинної профілактики атопії в майбутніх дітей.

2. На антенатальному етапі комплекс профрілактичних засобів, запропонований нами, базується на виключенні контакту вагітних жінок з атопічним захворюванням тільки з причинно-вагомими алергенами та своєчасному лікуванні загострень алергічних захворювань під час вагітності, що дозволить зменшити рівень сенсибілізації 
плода, попередити її формування та знизити рівень захворюваності на атопію у дітей.

3. Споживання жінкою різноманітних харчових продуктів під час вагітності тільки сприятиме формуванню харчової толерантності в майбутніх немовлят і, тим самим, є дієвим засобом профілактики алергії у дітей раннього віку.

\section{СПИСОК ЛІТЕРАТУРИ}

1. Погоджувальний документ Асоціації дитячих алергологів та імунологів Росії // Первинна профрілактика алергії у дітей. - М., 2010. - С. 15-26.

2. Охотнікова О. М. Профрілактика алергії у дітей: сучасні можливості та перспективи / О. М. Охотнікова // Дитячий лікар. - 2011. - № 4. - С. 26-35.

3. Костроміна В. П. Етапи профрілактики алергійних захворювань у дітей / В. П. Костроміна, В. О. Стриж // Дитячий лікар. - № 2. - С. 48-50.

4. Беш Л. В. Профрілактика алергічних захворювань у дітей: наскільки можливою вона є сьогодні? / Л. В. Беш // Дитячий лікар. - 2009. - № 1. - С. 7-13.
ПЕРСПЕКТИВИ ПОДАЛЬШИХ ДОСЛІДЖЕНЬ. У ПОдальшому планується на основі визначених у вагітних жінок з обтяженим алергологічним анамнезом генетичних та імунологічних показників розробити критерії ризику виникнення атопічних захворювань у дітей після народження. Ми пропонуємо включити отримані нами результати до комплексу превентивних заходів для попередження розвитку атопічних захворювань дитячого віку, починаючи вже з антенатального періоду.

5. Казначеєва Л. Ф. Профрілактика алергічних захворювань у дітей групи ризику : керівництво для лікарів / Л. Ф. Казначеєва. - М., 2009. - 90 с.

6. International consensus conference on atopic dermatitis II (ICAAD II): clinical update and current treatment strategies / C. Ellis, T. Luger, D. Abeck [et al.] / Br. J. Dermatol. - 2003. Vol. 148 (Suppl. 63). - P. 3-10.

7. Muraro A. EAACI food allergy and anaphylaxis guidelines. Primary prevention of food allergy / A. Muraro // J.Allergy. - 2014. - Vol. 69(5). - P. 590-601.

8. Про організацію амбулаторної акушерськогінекологічної допомоги в Україні : наказ МОЗ України від 05.07.2011 р. № 417.

Отримано 15.02.16 